\title{
Diagnosis of canine demodicosis: comparative study between hair plucking and adhesive tape tests*
}

\section{Diagnóstico da demodicose canina: estudo comparativo entre tricograma e teste da fita adesiva}

\author{
Gabrielle Márcia Marques Cury, ${ }^{* *}$ Sílvia Trindade Pereira, ${ }^{* * *}$ Larissa Silveira Botoni, ${ }^{* * *}$ Renato Dornas de Oliveira Pereira, ${ }^{* * *}$ \\ Thalita da Costa Telles, ${ }^{* *}$ Ana Paula Ferreira, ${ }^{* *}$ Adriane Pimenta da Costa-Val ${ }^{\star * * *}$
}

\begin{abstract}
Demodicosis is a common parasitary dermatopathy in dogs, resulting from excessive proliferation of Demodex canis mite, a natural inhabitant of dog's skin. Definitive diagnosis is classically established through microscopic examination of deep skin scrapings obtained from affected areas, in which numerous adult mites and/or immature forms are observed. Although considered as the golden pattern for the disease diagnosis, this technique is difficult to be performed in some parts of the body, as face, eyelids and interdigital areas, besides causing pain in the dog and discomfort to the owner. Two less invasive diagnostic methods, the hair plucking and the adhesive tape test are described. Although these methods are well known, only few studies about their sensitivity were found in the literature. In the present study, tests were conducted on 40 dogs previously diagnosed with demodicosis through deep skin scrapings. At adhesive tape test, 30 of 40 samples were positive, evidencing $75 \%$ of sensivity, while at hair plucking, mites were observed in 29 samples, leading to a sensivity of $73 \%$. These results do not differ statistically and suggest that adhesive tape test and hair plucking tests can be used on clinical routine as first choice primary tests for canine demodicosis as they offer more comfort to animal and its owner. Interestingly, the presence of pyoderma raised the sensibility of both tests to $100 \%$. However, deep skin scrapings must be done for diagnosis confirmation whenever the results of these two methods are negative.
\end{abstract}

Keywords: dog diseases, medical examinations, specimen handling, skin diseases.

\begin{abstract}
Resumo
A demodicose é uma dermatopatia parasitária comum na espécie canina que ocorre devido à proliferação excessiva do ácaro Demodex canis, habitante natural da pele do cão. O diagnóstico definitivo da doença é classicamente estabelecido através de raspado de pele profundo, quando são observadas, ao microscópio, parasitas adultos e/ou formas imaturas do ácaro. Esta técnica tem algumas características indesejáveis como a dor provocada nos animais, o que incomoda seus proprietários. Além disso, é de difícil realização em alguns sítios, como face, pálpebras, patas e interdígitos. Este estudo teve como objetivo avaliar a sensibilidade de dois métodos diagnósticos menos invasivos: a evidenciação dos ácaros em pelos avulsionados e o teste da fita adesiva. Apesar de serem testes bem consolidados, poucos estudos relativos à sua sensibilidade foram encontrados na literatura. Neste estudo, os testes foram conduzidos em 40 animais diagnosticados positivamente para demodiciose através de raspado de pele profundo. $\mathrm{Na}$ fita adesiva, 30 de 40 amostras apresentaram resultado positivo, evidenciando $75 \%$ de sensibilidade, enquanto na avulsão de pelos 29 amostras foram positivas, mostrando sensibilidade de 73\%. Tais resultados não diferiram estatiscamente e sugerem que o teste da fita adesiva, bem como a avulsão de pelos podem ser utilizados na rotina clínica de diagnóstico da doença. Na presença de piodermite a sensibilidade de ambos os testes foi de $100 \%$. No entanto, o raspado de pele profundo deve ser feito para confirmação do diagnóstico sempre que estes dois testes apresentarem resultados negativos.
\end{abstract}

Palavras-chave: doenças do cão, doenças da pele, manejo de espécimes, exames médicos.

\section{Introduction}

Demodicosis is a common parasite dermatopathy in dogs, resulting from excessive proliferation of Demodex canis mite, a natural inhabitant of hair follicles and rarely of the sebaceous glands of the animal's skin (Scott et al., 2001). Dogs acquire the commensal mite during the first two or three days of life, through direct contact with the bitch during lactation (Mason et al., 1996; Scott et al., 2001). The disease development seems to be mainly related to specific cellular immunocompetence for this mite, which has a hereditary feature (Scott et al., 2001). Parasite specific immune deregulation, either inherited or acquired, is considered the underlying pathogenic mechanisms

*Recebido em 1 de julho de 2013 e aceito em 13 de outubro de 2013.

** Médica Veterinária Autônoma.

***Médico Veterinário, aluna do curso de Mestrado em Ciência Animal, EV, UFMG, Belo Horizonte, MG, Brasil.

${ }^{* * * *}$ Professora Associada do Departamento de Clinica e Cirurgia Veterinárias, Escola de Veterinária (EV) Universidade Federal de Minas Gerais (UFMG), Belo Horizonte, MG Brasil. Autor para correspondência: e-mail adriane@ufmg.br 
of generalized demodicosis. In contrast, the localized form of the disease occurs probably due to immaturity of skin immune system and/or unspecified local insult (Kraviec e Gaafar, 1980, Scott et al. 2011).

Canine demodicosis can be seen in two clinical presentations that largely differ in clinical course and prognosis. Localized demodicosis involves up to five restricted areas of alopecia, erythema, hyperkeratosis, seborrhea, discreet or absent pruritus, and occurs more commonly on face, head and limbs. It has a benign course and most of the cases resolve spontaneously. On the other hand, generalized demodicosis usually affects more than five areas of the body, larger areas or the entire animal's body (Scott et al., 2001, Hnilica, 2012). Demodicosis cases are also subdivided according to the animal's age at the onset of the disease: juvenile demodicosis is presented in animals with less than two years of age, while adult demodicosis occurs after that age. The juvenile presentation is much more common and has a more favorable prognosis, while the adult demodicosis can really be life threathening, as they are associated to serious predisposing factors, such as immunosuppressive diseases or malignant neoplasias. Other less frequent disease presentations are pododemodicosis, restricted to distal extremities of limbs and can be the remainder form of an unhealed generalized demodicosis, and also extern ceruminous otitis, which can accompany other more generalized lesions (Scott et al., 2001). Generalized bacterial skin infection almost invariably accompanies the generalized form of the disease (Muller et al., 2012).

Definitive diagnosis is classically established through microscopic examination of deep skin scrapings obtained from affected areas, where numerous adult mites and/or immature forms are observed (Kwochka, 1993; Ginel, 1996; Curtis, 2001; Scott et al., 2001; Mueller, 2005; Mueller et al,, 2012). This technique causes pain in the dog and, consequently, discomfort to the owner and may be difficult to perform in some areas, such as eyelids, paws and interdigital areas. In rare cases, skin biopsies can be necessary to determine the diagnosis, especially in Shar-Pei dogs, due to their innate mucinosis cutis or in fibrotic lesions from any dog. In both situations, parasite visualization is difficult (Kwochka, 1993; Ginel, 1996; Scott et al., 2001; Mueller et al., 2012).

The hair plucking and the adhesive tape methods were described in other studies (Saridomichelakis et al., 2007; Mueller et al., 2012). These methods have been proposed as additional diagnostic method for demodicosis, especially for generalized forms of disease, seborrheic forms or areas that are difficult to scrape. Both methods present $100 \%$ specificity and as the deep skin scrapings, they are based on direct microscopic parasite observation. (Mueller, 2005; Saridomichelakis et al., 2007; Mueller et al., 2012; Pereira et al., 2012).

\section{Material and methods}

In the present study, tests were conducted on 40 dogs with generalized (23) and localized (17) demodicosis (Sott et al., 2001), from various breeds, with age ranging from 4 months to 10 years, from both sexes, previously diagnosed with demodicosis through deep skin scrapings. Superficial bacterial skin infection or pyoderma was diagnosed in 8 of the 23 dogs with generalized demodicosis and in 4 of the 17 animals with localized demodicosis. The presence of pyoderma was suspected by presence of papules or pustules and confirmed by ordinary modified Giemsa (Panotico-Laborclin) stained impression smears, in which large number of intra or extra cellular bacterial organisms could be seen.

Deep skin scrapings were performed as described by Kwochka (1993). Firstly, if needed, the suspected area was clipped with scissors and cleaned with $\mathrm{NaCl} 0,9 \%$ solution. Then, skin was gentle pressed between fingers, to expel mites from follicles and skin was repeatedly scrapped, in the hair growing direction, using 10 scalpel blade soaked in mineral oil, until capillary bleeding, to ensure that epidermis was removed. The material was suspended in some mineral oil drops at a glass slide. The sample was covered with a slip and examined with an optical microscope, at 40X magnification.

The hair plucking test consists on microscopic observation of detached hair and was done as described by Curtis (2001) and Mueller (2005). A $16 \mathrm{~cm}$ Crile haemostatic forceps was used for samples acquirement. In order to improve contact between the forceps and hairs, the pressing extremities covered with latex tubes. The hairs were detached from perilesional or partial alopecic areas, put over a glass slide with mineral oil, and covered with a glass slip. The samples, one of each diseased area, were examined with an optical microscope, at $40 \mathrm{X}$ magnification, with special attention to hair bulbs, where mites are more easily found. Occasionally, mites are not seen on the first investigation but few minutes under microscope lamp light and heat, allow mites to be dispersed from the hair. Therefore, negative samples were re-examined some minutes later.

The adhesive tape test was as described by Curtis (2001) and Mueller (2005). Ordinary transparent tape, with an adherent side, was placed over injured areas and the skin was squeezed between two fingers. After that the tape was put over a glass slide, with the adherent side facing down. The preparation was examined with an optical microscope, at 40X magnification.

In these three tests - deep skin scraping, hair plucking and adhesive tape - the samples were collected in the same area and positive diagnosis is established when Demodex adult mites are observed in a large number,i.e., more than five adult forms per microscope field or when the mite's evolutive forms are visualized - eggs, larvae and nymphs.).

The sensitivity of both methods was calculated by the formula proposed by Di Magno et al., (1977), in which the number of positive patients in a particular test is multiplied by 100 and then divided by the number of tested patients. The same formula was applied when tests were confronted to localized and generalized forms of the disease The comparison of the adhesive tape and the hair plucking test was performed by Paired t-test, for which 0 was attributed to negative results and 1 to positive ones. The influence of pyoderma was tested by T-Student test.

\section{Results and discussion}

At adhesive tape test, 30 of 40 samples were positive, evidencing $75 \%$ sensitivity. By the other hand, mites were observed in 29 of the 40 dogs when the hair plucking was performed, demonstrating $73 \%$ of sensitivity for this method. These results do not differ statistically, regardless of the form of the disease. Sensitivity of both methods was inferior to that of deep skin scrapings - by definition, $100 \%$ - as also evidenced by other 
authors: Saridomichelakis et al., (2007) found $85,1 \%$ of hair pluckings for demodicosis diagnosis in a study with 67 positive dogs. By the other hand, Pereira et al., (2012) found no statically significant difference when comparing adhesive tape test and skin scrapings and Beco et al., (2007) also found no statistical significant difference when comparing hair plucking and skin scrapings. The variance between these studies and the present one can be attributed to the fact that the authors previously mentioned squeezed the diseased area before taking the samples by either hair plucking or adhesive tape test,

When the form of the disease was considered, sensitivity of both tests showed some change: sensitivity of the adhesive tape test was higher on generalized demodicosis $(85 \%)$ than on the localized form (56\%). By the other hand, the sensitivity of hair pluckings for localized demodicosis was $47 \%$ while for generalized was $80 \%$. Saridomichelakis et al., (2007), found a sensitivity of $85,1 \%$ of hair pluckings for demodicosis diagnosis in a study with 67 positive dogs, 30 with localized and 37 with generalized demodicosis. They found $70 \%$ of positive hair pluckings when considering only localized demodicosis and $97,3 \%$ considering only the generalized form. Although the sensitivity found in the authors study was higher, the results presented here also showed better results for generalized demodicosis.

Although described in the consulted literature (Gubash, 2006; Mueller et al., 2012), secondary pyoderma was not frequently found in this study: $8(34 \%)$ dogs presenting the generalized and $4(23 \%)$ with the localized form of the disease also showed secondary pyoderma. Interestingly, in the presence of pyoderma the sensitivity of both tests rose to $100 \%$, regardless of the form of the disease. This raise of sensitivity can be attributed to a release of yet unknown immunosuppressant factors further aggravates the immune deregulation, thus stimulating the proliferation of $D$. canis (Mueller et al., 2012).

\section{Conclusion}

The results found suggest that adhesive tape test and hair pluckings can be used on clinical routine as first choice primary tests for canine demodicosis, as they offer more comfort to animal and owner. However, deep skin scrapings must be done for diagnosis whenever the results of these two methods are negative and the results are better if used on animals with generalized demodicosis because of the higher sensitivity of the tests.

\section{Acknowledgments}

\section{Ethical and Animal Welfare Committee}

This research was approved by the Animal Research Ethics Committee of Universidade Federal de Minas Gerais, protocol $43 / 2007$ and all the procedures were conducted in accordance with the ethical standards.

\section{References}

BECO, J. FONTAINE, K. BERGVALL and C. FAVROT Comparison of skin scrapes and hairplucks for detecting Demodex mites in canine demodicosis, a multicentre,prospective study 22nd Annual Congress of the ESVD-ECVD, 13-15 September 2007, Mainz, Germany.

CURTIS, C. F. Diagnostic Techniques and Sample Collection. Clinical Techniques in Small Animal Practice, v. 16, n. 4, p. 199206, 2001.

DI MAGNO, E. P.; MALGEADA, W. F.; GO, V. L. A prospective comparation of current diagnostic tests for pancreatic cancer. $N$. Engl. J. Med. n. 42, 1977.

GINEL, P. J. Demodicosis canina. Waltham Focus, Londres, v. 6, n. 2, p. 2-7, 1996.

HNILICA, K. A. Dermatologia de pequenos animais: Atlas colorido e Guia Terapêutico. 3. ed. Rio de Janeiro: Elsevier, Cap. 5, p. 123125. 2012.

GUBASH, R. Parasitic miticidal therapy Clinical Techniques in Small Animal Practice, n. 21, p. 135-144, 2006.

KRAVIEC, D. R., GAAFAR, S.M. Studies on the immunology of canine demodicosis. Journal of the American Hospital Association, v.16, p. $699-676,1980$.

KWOCHKA, K. W. Demodicosis. In: GRIFFIN, C. E.; KWOCHKA K. W.; MACDONALD. J. M. Current Veterinary Dermatology: The Science and Art of Therapy. Missouri: Mosby Year Book, Cap.7, p. 72-84. 1993.
MASON, I. S.; MASON, K. V.; LLOYD, D. H. A review of the biology of canine skin with respect to the commensals Staphylococcus intermedius, Demodex canis and malassezia pachydermatis. Veterinary Dermatology, n. 7, p. 119-132, 1996.

MUELLER, R. S. Diagnostic of ectoparasitc skin disease in small animal practice. In: CONGRESSO NAZIONALE MULTISALA SCIVAC, 50., 2005, Rimini, Italia. Proceedings... Rimini: SCIVAC; 2005. Acessed in March 31 2010. Online. Available in http://www. ivis.org/proceedings/scivac/2005/Mueller1_en.pdf?LA=1

MUELLER, R. S.; BENSIGNOR, E.; FERRER, L.;HOLM, B.; LAMARIE, S.; PARADIS, M.; SHIPSTONE, M. Treatment of demodicosis in dogs: 2011 clinical practice guidelines. ESVD and ACVD , Veterinary Dermatology, n. 23 p. 86-95, 21e ?2012.

PEREIRA, A.V.; PEREIRA, S.A.; GREMIÃO, I.D.F.; CAMPOS, M.P.; FERREIRA, A.M.R. Comparisson of acetate tape impression with squeezing versus skin scraping for the diagnosis of canine demodicosis. Australian Veterinary Journal, v., n. p. 1-3, 2012.?

?SARIDOMICHELAKIS, M.N.; KOUTINAS, A.F.; FARMAKI, R., et al. Relative sensivity of hair pluckings and exudate microscopy for the diagnosis of canine demodicosis. Journal compilation ESVD and ACVD, v.18, p.138-141, 2007.

SCOTT, D. W.; MULLER, G. H.; KIRK, R. W. Parasitic skin diseases. In: Small animal dermatology. Philadelphia: W. B. Saunders Company, 2001, Cap. 6, p. 417-516. 